\title{
The Lady in White
}

"Listen up youse fellas! I'm checking out that haunted house on Tui Street after school," Pita 'Poser' Paraone announced to his classmates before their teacher Matua Tane arrived for the morning lesson.

"Whose man enough to come with me?" he followed up quicky with his nose in the air.

There was plenty of lively chatter among them. They all knew where the haunted house was on Tui Street because it was behind their school, Kaikohe Intermediate on Park Rd, across the playing fields. Whenever a stray ball was unwittingly kicked into the overgrown backyard of that house, no one was brave enough to retrieve it on their own.

"Shhh! Matua Tane's here," said someone at the door.

Matua Tane greeted the class, "Tēnā koutou tamariki ma."

"Tena koe, Matua Tane," they replied.

He then asked how they were feeling today, "Kei te pēhea koutou i tenei rā?"

"Tino pai, Matua Tane."

He was pleasantly surprised to find the children quietly sitting up straight with their textbooks in front of them, ready to start. He sensed an air of excitement and speculated that perhaps today was the end of the week, and the children always looked forward to the weekend. 
He licked his right middle finger and flipped over the calendar on his desk. It read Friday $13^{\text {th }}$ of September 1985, which brought a smile to his face before he delivered the morning's lesson.

By lunch time the buzz of excitement about Pita Poser and the house on Tui Street spread like wildfire on the gossip grapevine, and the whole school knew, apart from the adults. During their break, the teachers even commented to each other puzzled about how their pupils seemed more 'hyper' than usual.

When the school day was over, a small crowd had gathered around Pita Poser, and he looked pleased with himself being the centre of attention all day.

"Pita, are you really gonna go into the haunted house?" asked Aroha Repia.

“Āe. That's right," Pita Poser replied defiantly.

"Do you know what happened there? I mean why is it haunted?" said Aroha's best friend Wikitoria Heke.

"An unsolved murder case. It happened there about ten years ago," said Pita Poser in a hushed voice. "A 32-yearold Pākehā lady was alone in the house while her husband was away on business. She went into the kitchen in her night gown in the middle of the night for a drink and disturbed a couple of burglars who hit her over the head with a blunt object from behind. There's still a pool of blood in the kitchen that won't dry up."

Some of the children shivered at the thought of this. It was like watching a horror story on TV but better, because this was real!

"What a load of teko!" said Tainui Hohepa, from behind them. 
They all turned to see a handsome tall athletic boy flashing his white teeth in a condescending sneer. Tainui's whānau had only just moved to Kaikohe from down the line two months ago. As the new kid in their class, he was just the person to take the wind out of Pita Posers sails.

"Where on earth did you get all this superstitious claptrap from?” Tainui enquired.

"If you must know, my father is a cop and he was there ten years ago. I was born on the same day she died," Pita Poser said.

"That explains the tragedy, but not the haunting. There are no such things as ghosts, no more than there is a Father Christmas or a Tooth Fairy?" Tainui added.

"I was getting to that part, if you let me finish," said Pita Poser. "When her husband returned to find his wife had been murdered, he was so grief stricken that he put the house up for sale and moved away a few months after her death."

Pita Poser bent his head, and this drew the crowd in closer.

He whispered, "People often report hearing windows and doors being opened and shut when no one is in the house. People interested in buying the house were put off because doors closed behind them and would lock on their own or locked doors would suddenly be wide open. Lights turned on and off on their own, and footsteps were heard throughout the house."

The children blinked nervously, frozen to their spot. 
He continued, "A figure, a lady in white has also been seen passing the window at night by neighbours and passersby and this ghostly figure is still seen to this day."

"Not even ow. It's all scare tactics to keep nosy parker people away," Tainui laughed.

“Alright then Mr Mōhio-Know-it-all. Why don't you come along this afternoon and check the house out with us, and see for yourself?" Pita Poser challenged.

Tainui didn't hesitate and accepted, “OK, anyone else coming, too?"

Wikitoria and Aroha both fancied Tainui, and this was a good opportunity to get close and spend time with him. They looked at each other, giggled coyly and said together, "We're in." The other children said they would stay at the front gate and watch them go in.

Pita Poser led the way across the school fields with the others in toe. On the way to Tui Street Tainui spoke to Wikitoria and Aroha, "What are you ladies up to this weekend?"

"We've got a land meeting at Ngawha, so I'll be busy at the marae all weekend," said Aroha.

"We've got whānau coming over āpōpō for my nan's 60th. We're having a hāngī and party for her. You should come over if you're not doing anything? It'll be cool as," Wikitoria beamed her smile as she looked into Tainui's green eyes.

"We're heading down to my uncle's place in Auckland tomorrow. We're off to the rugby game, Bledisloe Cup. Andy Dalton, Stu Wilson, Murray Mexted, Bernie Fraser and Gary Whetton are the best rugby players in the world, and the Ozzie's are gonna get the bash from the All Blacks again, the fourth time in a row. I wanna be an All Black one day," Tainui boasts as he spins his rugby ball on his 
finger like he saw the Harlem Globetrotters do with a basketball.

"That's choice, bro. You've certainly got the body," Wikitoria says as she looks down at his muscular legs admiringly, then up to the bulge in his shorts. Aroha giggles catching where Wikitoria has focused her attention and coughs loudly. Both turn with concern to see if she is alright.

"Frog in my throat," says Aroha.

They shortly arrived at 2 Tui Street, a 3-bedroom weatherboard house with well-established overgrown gardens and trees on an elevated quiet cul-de-sac with extended views over the surrounding area. A cluster of "FOR SALE" signs stood partly covered by the long unkept grass in the front of the property. There was literally no one in sight and Pita Poser was quick to point out the eerie silence.

"See there," Pita Poser said pointing at the moss-covered signs at the front. "Those signs have been there for months and the neighbours are terrified when anyone wants to visit the house. No one wants to buy a haunted house and that proves it."

"All I see is an empty house in need of a good clean, and that wilderness cleared out to bring it up to scratch," replied Tainui unimpressed.

"If we get caught inside, won't that be breaking and entering?" Wikitoria asked.

"Nobody will see us go in with all those overgrown trees, bushes and grass. Anyway, we'll just say we're looking for our lost ball," and with that Tainui threw his rugby ball through one of the broken windows. 
Long grass grabbed at their legs as they followed the path leading to the back. They silently approached the back door in hushed voices, and they looked up to see spider webs in each corner.

"Try it!" Tainui said in his normal voice and everyone jumped.

"Hang on," replied Pita Poser as he turned the handle. "Shit, its locked. I'll climb through that broken window and open the back door. Wait here."

"Why don't you ask the ghost to open the backdoor for us?" teased Tainui.

As the three of them waited, Aroha looked over the kneehigh grass that was once a lawn and back at the dirty windows where Pita Poser had jumped on top of a rubbish bin, unlatched the window, climbed through and disappeared inside.

“Gosh, Pita's brave, Aroha whispered nervously as looked around. "It must have been such a very long time since anyone's lived here." Pita Poser opened the back door that made a loud creaking noise.

"Haere mai whānau, come on in," Pita Poser said with a wide grin.

The house interior was dark and damp with a dead silence. The wallpapers were peeled off and curled on the floor and picture frames dangled on the wall. Green mold and spider webs covered the walls and ceilings as they entered the kitchen.

"Is this the place where she was murdered?" asked Wikitoria in a small voice.

The sound of the word "murdered" made their skin crawl. 
"Oh my God! Look!" Aroha pointed to the floor. "There's the pool of blood."

They all stared in horror at the glossy red stain on the black and white checkered linoleum floor.

"I'm getting the hell out of here," Wikitoria said in a panic.

To everyone's amazement, Tainui bent down and touched the crimson stained lino with his middle finger.

"That isn't blood," he mocked. "Someone spilled some red paint. Come on, I'm going to find my ball."

As he made his way to the front living room the floorboards creaked, and no one spoke.

"Hello! Any ghosts in here!" Tainui called out in a loud voice. "See? Nothing to be scared of."

The others jumped out of their skins and they nearly mimmied their pants.

"It's easy to show off in the daytime, but not when its nighttime when the ghost comes out," Pita Poser answered back. "You wouldn't dare come back here at night."

"Bet I would," said Tainui. "How much?"

“Ten bucks," replied Pita Poser.

"You don't have ten dollars, show me?"

Pita Poser pulled out a crisp ten dollar note from his pocket that he was given for his birthday. 
"OK, I've got a tenner too from doing lawns," Tainui said pulling out two $\$ 5$ notes from his top pocket.

Tainui spoke looking at Wikitoria, "Here, you hold our money. And let's hongi on it" as he clasped Pita Poser's hand, they bent forward and pressed their forehead and noses together.

"I'll leave my rugby ball over there on that sofa covered in dust, and come and pick it up at 10 o'clock tonight," Tainui returned and Pita Poser nodded in agreement, quickly adding, "We'll meet in the front garden ten minutes before, and wait for you there, alright?"

"Fine by me, just leave the backdoor open."

And with that they left the house relieved as they quietly made their way back to the street unseen and told the other children what they saw.

"Ka kite whānau. See youse just before ten," Tainui said as he ran off down the street waving behind him.

"Āe, see you then," the other three waved back.

When Tainui reached the corner and was out of earshot Pita Poser turned to the girls and said, "Taihoa. Tainui is a blow hard and I've got a plan."

"Watcha gonna do?" the girls enquired eyeing Pita Poser.

"I'll go into the house five minutes before Tainui arrives and wait for him there with a white sheet over me ready to scare him. Tell him I'm running late or something and that he might as well go in and get his ball." 
His watch read $9.50 \mathrm{pm}$ as Tainui took out his torch and put his backpack over his shoulders. He was grateful the full moon was out and lit up the path ahead to the empty house. It looked huge, scarier with its broken windows, dark grey shadows and surrounding trees.

“Is anyone here?" Tainui whispered.

Two figures appeared out of the bushes and said, "Over here."

"Where's Pita?" asked Tainui "Don't tell me he chickened out."

"No, he got a call from his mum and he's gone off to talk to her," said Aroha adding sympathetically, "You know you don't have to do this Tainui. You can always pull out you know."

"I'm not scared," he said boldly. "I'll be back here in ten minutes with my rugby ball, check your watches, and have my winnings ready."

Tainui made his way round to the backdoor and took a white sheet out of his backpack, adjusted it so he could see out of the two slits he made, turned his torchlight on and opened the door. He was grateful for Wikitoria's phone call earlier warning him of Pita's plan. She didn't think it was fair, and plus she liked him. Tainui said he thought she was pretty, and he liked her too, and for her not to worry. He would dress up in a white sheet of his own and scare Pita back and they'll all have a good laugh afterwards.

At that exact moment Pita Poser came flying out of the front door leaving it wide open.

"There really is a ghost in there!" he gasped. 
Wikitoria and Aroha stood up from behind the bush wide eyed and mouth gaping open.

"I saw it coming towards me," Pita Poser said in his next breath.

"What happened?" Aroha said as she grabbed his hand and lowered him to their hiding place, managing to calm him down a little. "Tell us what you saw," she requested.

"I was behind the sofa in the front room when I heard that same creaking noise in the floorboards, so I jumped up yelling at the same time. Then I saw a white-ish shape floating towards me and it was reaching out for me. I threw off my sheet and got the hell out of there through the front door. It was horrible."

Wikitoria started to laugh and they both looked at her puzzled.

"E koe! Serves you right Pita," Wikitoria laughed out even louder. "I thought your plan was so mean, so I rang up Tainui and told him. He said he'd trick you back, that was Tainui you saw in a white sheet."

"Thank God for that," Pita Poser let out a long sigh of relief. "I've never been so scared in my life."

"Tainui will be out in few minutes and then how about we go get some MacDees downtown, ok?” Wiktoria grinned.

Tainui was bored as he switched on the torch and looked down at his watch wandering where Pita was. It felt like hours but only five minutes had passed as he sat on the sofa throwing his ball in the air and catching it. He looked oddly across the room and wondered why the front door was wide open and when that idiot was going to turn up. Then he heard the familiar creak of the floorboards and a white figure coming towards him. 
He jumped up screaming in the middle of the room where he knew Pita would see him.

"Alright, the games up," Tainui said surprised Pita didn't scarper. "Let's call it quits."

But with arms outstretched the white figure kept floating towards him, getting closer and closer... reaching out.

The End 